\title{
Influence of variants of Fcg receptor IIA on the European league against rheumatism responses to anti-tumour necrosis factor alpha therapy in psoriatic arthritis
}

\author{
J Ramirez ${ }^{1 *}$, J L Fernadez-Sueiro ${ }^{4}$, R Lopez ${ }^{2}$, C Montilla, B Suarez ${ }^{2}$, C Moll $^{1}$, R Rodriguez ${ }^{2}$, F Blanco ${ }^{4}$, M Alsina ${ }^{3}$, \\ R Sanmarti ${ }^{1}$, F Lozano $^{2}$, J Cañete ${ }^{1}$
}

From 5th European Workshop on Immune-Mediated Inflammatory Diseases

Sitges-Barcelona, Spain. 1-3 December 2010

\section{Introduction}

The efficacy of biological therapies currently used in psoriatic arthritis depends not only on their blocking effect on the targeted molecule but also on the affinity of genetically defined variants of the Fc-gamma receptors for the constant portion (Fc fragment of IgG1).

\section{Aim}

To determine whether polymorphisms in Fc-gamma receptor IIA influence clinical efficacy in patients with psoriatic arthritis treated with tumor necrosis factor alpha inhibitors.

\section{Patients and methods}

The study population comprised 110 patients $(52.7 \%$ males and $47.3 \%$ females) with psoriatic arthritis refractory to $15 \mathrm{mg}$ or more of methotrexate/week. Infliximab (33.6\%), etanercept (50.9\%) or adalimumab (15.5\%) were initiated, and patients were evaluated after 12 and 24 weeks using the EULAR response criteria. Genotyping of FCGR IIA-H131R polymorphism was performed by allele-specific PCR and PCR sequence-based typing. The chi-square test was used to compare response rates across Fc-gamma receptor IIA genotype.

\section{Results}

No significant differences were found at 12 and 24 weeks in EULAR responses between patients with high affinity alleles (FCGRIIA HH/HR) and patients with low

${ }^{1}$ Rheumatology, Hospital Clinic, Barcelona, Spain

Full list of author information is available at the end of the article affinity alleles (FCGRIIA RR) (Tables 1 and 2). However, there was a trend to a better response among patients with high affinity alleles.

\section{Conclusion}

These results suggest that FCGR IIA-H131R polymorphism has low influence in the clinical efficacy of anti-TNF therapies in patients with psoriatic arthritis. Although different to previously reported results in rheumatoid arthritis [1], these results can be explained because of the better and more prolonged response to anti-TNF therapy in psoriatic arthritis than in rheumatoid arthritis. In addition, in this study we analyzed patients with three different anti-TNF-alpha therapies.

Table 112 weeks EULAR Response FCGRIIA

\begin{tabular}{llll}
\hline & HH+HR & RR & Total \\
\hline Null (\%) & 10.1 & 26.3 & 13.3 \\
Moderate (\%) & 27.8 & 10.5 & 24.5 \\
Good (\%) & 62.0 & 63.2 & 62.2 \\
\hline
\end{tabular}

$p=0.086$.

Table 224 weeks EULAR response FCGRIIA

\begin{tabular}{llll}
\hline & HH+HR & RR & Total \\
\hline Null (\%) & 8.9 & 26.3 & 13.3 \\
Moderate (\%) & 27.8 & 15.8 & 25.5 \\
Good (\%) & 63.3 & 57.9 & 62.2 \\
\hline$p=0.090$ & & &
\end{tabular}




\section{Author details}

${ }^{1}$ Rheumatology, Hospital Clinic, Barcelona, Spain. ${ }^{2}$ Immunology, Hospital

Clinic, Barcelona, Spain. ${ }^{3}$ Hospital Clinic, Barcelona, Spain. ${ }^{4}$ Rheumatology,

Complejo Hospitalario Juan Canalejo, La Coruña, Spain.

Published: 25 November 2010

\section{Reference}

1. Cañete JD, et al: . Ann Rheum Dis. 2009, 68:1547-52.

doi:10.1186/1479-5876-8-S1-P38

Cite this article as: Ramirez et al:: Influence of variants of Fcg receptor

IIA on the European league against rheumatism responses to anti-

tumour necrosis factor alpha therapy in psoriatic arthritis. Journal of

Translational Medicine 2010 8(Suppl 1):P38.

Submit your next manuscript to BioMed Central and take full advantage of:

- Convenient online submission

- Thorough peer review

- No space constraints or color figure charges

- Immediate publication on acceptance

- Inclusion in PubMed, CAS, Scopus and Google Scholar

- Research which is freely available for redistribution

Submit your manuscript at www.biomedcentral.com/submit 